Vol. 23, No. 2, pp. 200 210, 2020.

\title{
Development and application of ex-solution nanocatalyst
}

\author{
Jun Hyuk Kim ${ }^{1}$, Jun Kyu Kim ${ }^{1}$, WooChul Jung ${ }^{1 \dagger}$ \\ ${ }^{1}$ Department of Materials Science and Engineering, Korea Advanced Institute of Science and Technology (KAIST), \\ Daejeon 34141, Republic of Korea
}

\section{용출 현상 기반 나노촉매의 개발 및 응용}

\author{
김준혁, 김준규, 정우철 ${ }^{\dagger}$ \\ 1한국과학기술원 (KAIST) 신소재공학과
}

(Received May 4, 2020; Accepted June 2, 2020)

\begin{abstract}
Supported catalysts are at the heart of manufacturing essential chemical, agricultural and pharmaceutical products. While the longevity of such systems is critically hinged on the durability of metal nanoparticles, the conventional deposition/dispersion techniques are difficult to enhance the stability of the metal nanoparticles due to the lack of control over the interaction between metal-support. Regarding this matter, ex-solution has begun to be recognized as one of the most promising methodologies to develop thermally and chemically robust nanoparticles. By dissolving desired catalysts as a cation form into a parent oxide, fine and uniformly distributed metal nano-catalysts can be subsequently grown in situ under reductive heat treatment, which is referred to ex-solution. Over the several years, ex-solved analog has resulted in tremendous progress in the chemical-electrochemical applications due to the exceptional robustness coupled with ease synthesis. Herein, we describe the ex-solution process in detail which therein introducing the unique characteristics of ex-solved particles that distinguish them from conventionally dispersed nanoparticles. We then go through the history of science regarding the ex-solution phenomena and summarize several major research achievements which embrace the ex-solved nanoparticles to markedly promote the catalytic performances. In conclusion, we address the remaining challenges and the future perspectives of this rapidly growing field.
\end{abstract}

Keywords: ex-solution, catalyst, phase transition, ceramic fuel cell

Corresponding Author: WooChul Jung

E-mail: wcjung@kaist.ac.kr 


\section{1. 서론}

고활성 및 고내구성을 나타내는 담지 촉매(supported catalyst)의 개발은 불균일 촉매 (heterogeneous catalyst) 분야의 핵심기술로서 범지구적인 주목을 받고 있다. 일반적으로, 담지 촉매는 산화물 형태의 지지체( 혹은 담체, support) 위에 금속 나노입자(nanoparticle) 가 분산된 형태로 구성되어 있는데, 이러한 담지 촉매들 은 친환경 에너지 장치, 센서, 배기가스 제어 시스템 그 리고 수소생산용 개질기 등 매우 폭넓은 분야에서 활용 되고 있다. 담지 촉매 시스템에서 가장 개선되어야 할 부분은 촉매 자체의 수명으로, 통상적으로 이는 금속 나 노입자의 안정성에 의해 크게 영향을 받는다. 현재까 지, 금속 나노입자들은 함침법(impregnation), 공침법 (co-precipitation), $\mathrm{PVD}, \mathrm{CVD}$ 와 같은 증착 기법을 이 용하여 만들어졌다. 이러한 기존의 방식들은 여러 분야 에서 손쉽게 이용될 수 있다는 장점이 있었지만, 지지체 와 나노 입자사이의 상호작용을 조절하기 어렵고 따라 서 나노 촉매의 수명을 증진시키기에 어려움이 있다. 특 히, 담지 촉매의 역할이 막중한 고온 반응 과정 중 반응 활성점인 금속 나노입자들이 서로 뭉쳐 조대화되기 때 문에, 나노입자의 부피 대비 표면적이 감소하게 됨에 따 라 촉매의 성능이 급격히 열화되는 현상이 발생하게 된 다. 이에 따라 금속 나노촉매의 안정성을 향상시키기 위 한 다양한 노력들이 이루어져 왔는데, 대표적으로는 금 속 나노입자의 조대화를 막기 위해 나노입자 표면에 물 리적인 산화막을 도포하는 방법이 있다. 하지만 산화막 을 추가로 도포하는 과정은 담지 촉매를 제작하는 데에 추가적인 공정을 요구하므로 실용성과 경제성이 떨어지 고, 또한 산화막에 의해 덮힌 금속 나노촉매가 반응물과 접촉할 표면적이 줄어 촉매 성능이 감소한다는 문제도 수반되었다. 그러므로, 담지 촉매의 수명을 늘리기 위해 안정성이 뛰어난 고내구성 금속 나노촉매를 만드는 새 로운 기술들이 광범위하게 연구되고 있다.

이러한 연구 동향에 응하여 최근에는 용출법 $(\mathrm{ex}-$ solution)으로 만들어진 금속 나노입자들이 그 뛰어난 열적/화학적 안정성에 의해 주목을 받고 있다 (Fig. 1).

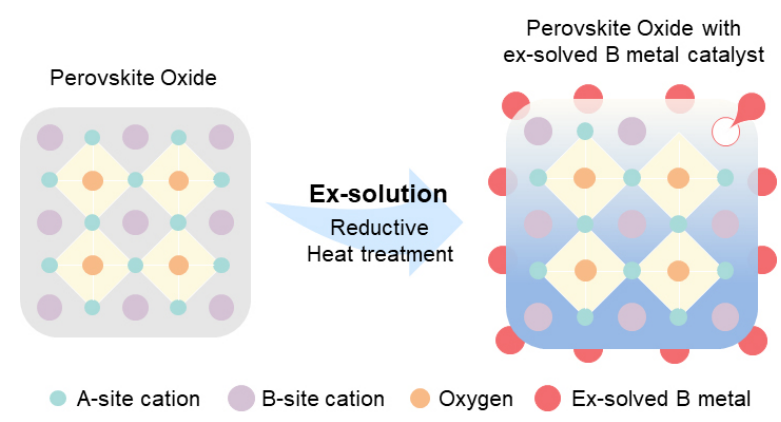

Fig. 1. 용출(ex-solution)의 개략도.

용출법이란, 촉매 활성 특성을 지니는 전이금속을 산화 분위기에서 모상이 되는 산화물 지지체에 이온의 형태 로 균일하게 고용시킨 후, 단 한번의 환원 열처리를 통 해 금속 나노입자를 산화물 지지체 위에 고르게 성장시 키는 방법을 말한다. 이렇게 만들어진 나노입자들은 지 지체에 표면에 박혀 있는(socketed) 형상을 띄고 있어, 고온에서도 나노 입자들이 잘 뭉치지 않으면서, 탄화수 소를 지니는 기상분위기에서도 탄소 침적에 높은 저항 성을 가지는 특성이 보고되었다. ${ }^{1,2)}$ 용출법의 발견 이후, 많은 연구자들이 이러한 흥미로운 현상을 이용하여 다 양한 분야에 촉매 특성 및 안정성을 향상시키려는 노력 을 해왔는데, 특히, 기존에 금속 나노촉매의 역할을 기 대하기 어려웠던 고온 산화물 연료전지에서 큰 발전이 이루어졌다.

본 논문에서는 현재까지 보고된 용출법에 대한 기본 개념과 더불어 관련된 특성들을 소개하고, 더 나아가 현 재 용출법이 적용되고 있는 다양한 응용 분야들에 대해 체계적으로 정리해보고자 한다.

\section{2. 용출법}

앞서 서론에서도 간략하게 언급하였듯이, 용출법이 란 상대적으로 환원이 되기 쉬운 전이금속 (예: $\mathrm{Fe}, \mathrm{Co}$, $\mathrm{Ni}, \mathrm{Cu}, \mathrm{Pt}, \mathrm{Ag}$ 등)을 산화 분위기에서 모상이 되는 산 화물 지지체에 이온의 형태로 고용시킨 후, 환원 열처리 와 이에 따른 전이금속의 선택적 환원을 통해 금속 나노 촉매를 실시간, 그리고 자발적으로 산화물 지지체 표면 
CERAMIST

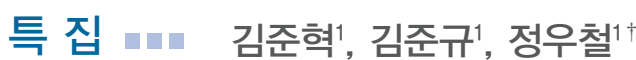

에 형성시키는 기법 혹은 현상을 의미한다. 산화물 지지 체는 주로 페로브스카이트 구조를 가지는 물질들이 중 점적으로 연구되었는데, 이는 페로브스카이트 산화물 이 가지는 광범위한 물질 조합에 대한 이점에 기반한다. $\mathrm{ABO}_{3}$ 화학식을 가지는 페로브스카이트 산화물들은 일 반적으로 B-site 격자에 전이 금속 이온들을 수용할 수 있고, 화학식의 화학양론 (stoichiometry)이 조금 벗어 나더라도 탄력적으로 안정한 산화물 모상을 형성한다는 장점이 있다. 실제로, $\mathrm{A}, \mathrm{B}$ 격자에 각각 수용되는 양이 온 사이의 비화학양론(non-stoichiometry)의 조절을 통해서 더 효과적이면서 다양한 조성을 가지는 나노 입 자를 얻는 방법이 Irvine 그룹에 의해서 소개되었다 (식 $1,2{ }^{1}{ }^{1}$ 특히 A-site에 수용되는 양이온을 양을 B-site 에 수용되는 양이온의 양보다 적게 하면, B-site 양이 온이 과다한 상태의 페로브스카이트 산화물 격자가 형 성되는데, 페로브스카이트 산화물은 A-site : B-site 의 비율이 $1: 1$ 인 형태가 보다 안정적인 형태이므로 상 대적으로 많은 B-site의 전이 금속 양이온들을 환원 분 위기에서 손쉽게 용출할 수 있다. 따라서 A-site 결핍 (deficiency)는 보다 쉬운 용출법을 위한 효율적인 전
략이라고 할 수 있다. 하지만 최근에는 페로브스카이 트 산화물에서 벗어나 다양한 모상 (예: Ruddledsonpopper, double perovskite 및 fluorite 구조)에서 용출 법을 활용하려는 연구들 또한 진행되고 있다.

$$
\begin{aligned}
& A_{1}-{ }_{\alpha} B O_{3-\delta} \rightarrow(1-\alpha) A B O_{3-\delta}+\alpha B \\
& A B O_{3-\delta} \rightarrow(1-\alpha) A B O_{3-\delta}+\alpha A O+\alpha B
\end{aligned}
$$

환원 열처리를 통해 만들어진 용출 나노입자들은 매 우 특이하게도 산화물 지지체 표면에 부분적으로 박혀 있는 형상을 나타내고 있는데, 이것이 용출법에 의해 만 들어진 담지 촉매의 가장 핵심이라고 할 수 있다 (Fig. 2). ${ }^{2}$ 이렇게 나노입자들이 socket의 형태로 박혀있다는 사실은 선택적 화학 에칭을 통해서도 알 수 있는데, 실 제로 용출된 $\mathrm{Ni}$ 나노입자와 지지체를 질산 처리하자, 용 출되어 형성된 $\mathrm{Ni}$ 이 녹아 사라지고, 결과적으로 지지체 에는 금속 나노입자가 위치하였던 구멍만이 남는 결과 가 보고되었다. 따라서 부분적으로만 지지체와 금속 촉 매가 접촉하고 있는 기존의 외부 증착 공정으로 만들어 진 담지 촉매 시스템과는 달리, 용출된 나노 입자들은
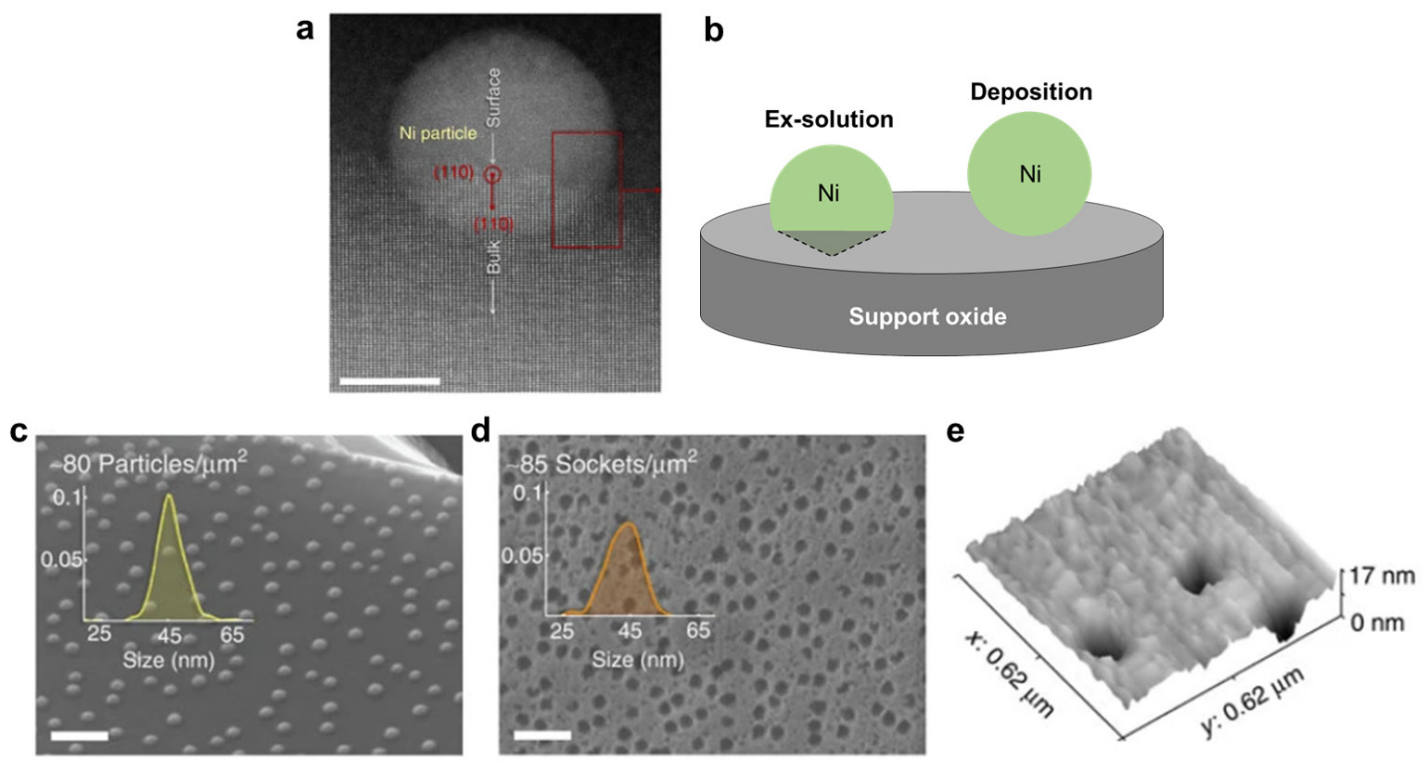

Fig. 2. (a) Ni의 용출을 묘사한 투과전자현미경 사진, 스케일바 $=10 \mathrm{~nm}$ (b) 용출된 나노입자와 증착된 나노입자를 나타낸 모식도, (c) 질산 에칭을 진행하기 전과 (d) 후의 투과전자현미경 사진, 스케일바 $=200 \mathrm{~nm},(\mathrm{e})$ 원자현미경 (Atomic force microscopy)를 통해 관찰 한 에칭된 후의 표면? 
a

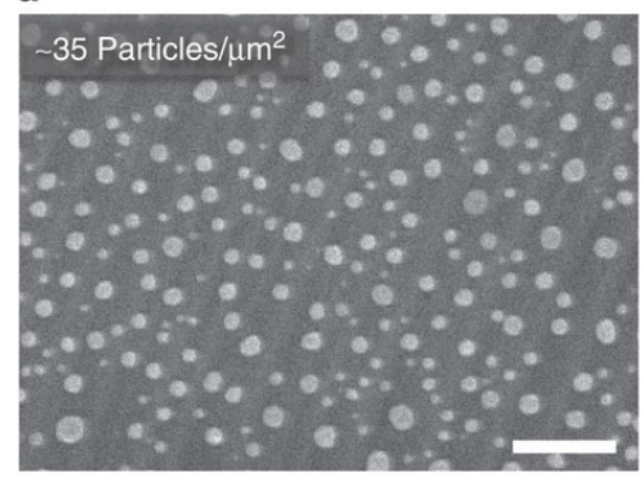

c

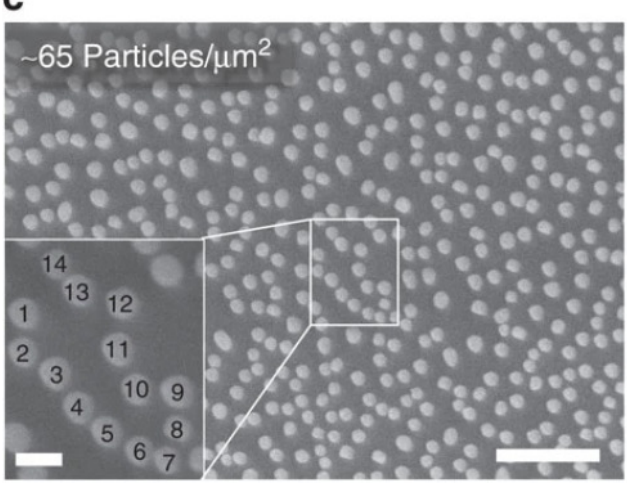

b

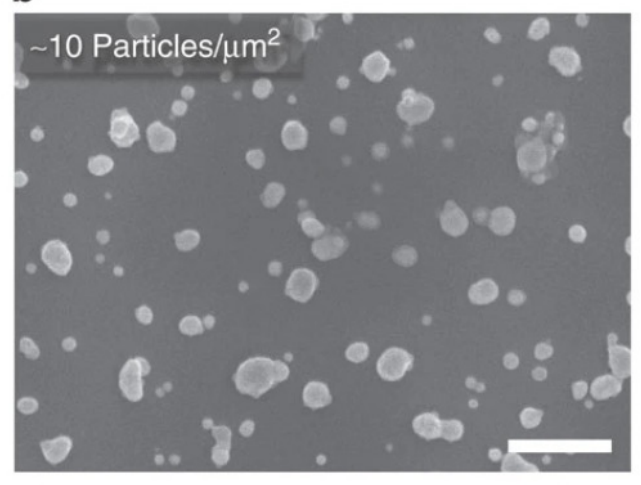

d

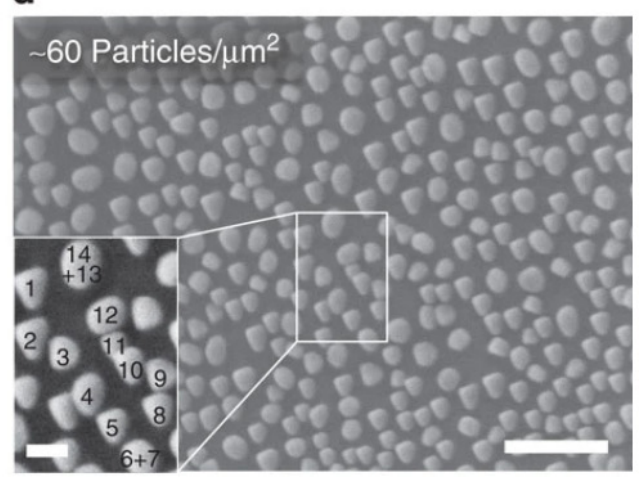

Fig. 3. (a) 열처리 전과 (b) 후의 증착 기법을 이용하여 만든 나노입자의 주사전자현미경 사진 $\left(\mathrm{H}_{2}, 650^{\circ} \mathrm{C} 24\right.$ 시간과 $800^{\circ} \mathrm{C} 6$ 시간), (c) 열처 리 전과 (d) 후의 용출법을 이용하여 나노입자의 주자전자 현미경 사진 $\left(5 \% \mathrm{H}_{2} / \mathrm{Ar}, 900^{\circ} \mathrm{C} 70\right.$ 시간), 스케일바 $=500 \mathrm{~nm}$ 및 확대 = $100 \mathrm{~nm}^{2}$.

지지체에 강하게 고정되어 있고, 이에 특이한 물리/화학 적 거동을 나타내는 연구들이 많이 보고되고 있다.

그중에서도, 용출 나노입자는 고온 및 탄화수소 분위 기에서의 반응에서 그 장점이 두드러지게 나타나게 된 다. 실제로 외부 증착 기법을 이용하여 만든 나노입자와 비교해보면, 증착 기법을 통해 합성 및 분산된 나노입자 들은 비교적 낮은 온도인 650도와 800도에서 열처리 후 나노입자의 수가 크게 감소함을 확인 할 수 있지만, 용 출법으로 생성된 나노입자들은 상대적으로 고온인 900 도에서도 그 수와 분포를 유지한다 (Fig. 3).

또한, 증착 기법으로 형성된 나노입자는 지지체와의 충분한 상호작용이 부족하여, 메탄 개질과 같은 탄화수 소 활성 반응 중 탄소 침적 및 탄소 섬유 성장으로 인해 나노입자가 지지체에서 탈착되어 촉매 특성에 심각한 문제를 유발했지만, 용출법으로 형성된 입자들은 지지
체에 강하게 고정되어 있으므로 탄소 침적 및 탄소 섬유 성장이 다른 반응기작으로 발생하여 나노입자의 탈착 문제가 발생하지 않았다 (Fig. $4^{2)}$ ). 따라서, 용출법은 기 존의 증착 공정으로 제작된 담지 촉매 대비 훨씬 진보된 촉매 특성과 내구성을 나타내고 있고, 이러한 다양한 이 점들로 인해 용출법은 고온 촉매 반응을 수반하는 다양 한 화학/전기화학 응용 분야에서 크게 각광받고 있으며, 다양한 지지체 및 나노입자의 조성 및 조합에 대해서 연 구가 활발하게 진행되고 있다.

\section{3. 최신 연구 동향}

\section{1. 용출의 활용}

용출법은 Irvine 그룹에서 2013년에 Nature Chemistry 에 소개한 연구 이후에 큰 주목을 받기 시작했지만, 유 
a

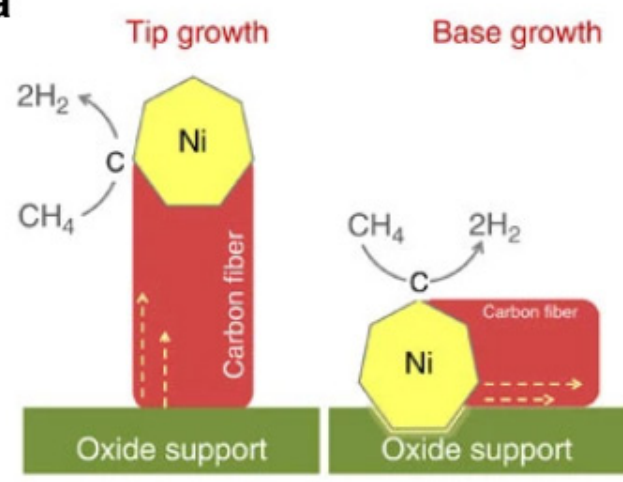

b

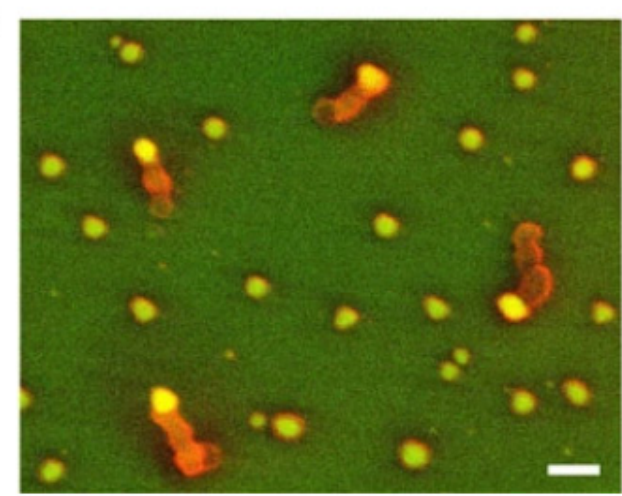

Fig. 4. (a) 탄소 침적 및 탄소 섬유 성장을 나타내는 모식도, (b) 용출법으로 형성된 Ni의 탄소 침적 실험 결과를 나타낸 주사전자현미경 사 진, 스케일바 $=100 \mathrm{~nm}^{2}$.

사한 현상의 학문적인 보고는 그보다 대략 10 년 전인 2002년에도 이루어졌다. Y. Nishihata를 필두로 한 연 구진은 $\mathrm{LaFe}_{0.57} \mathrm{Co}_{0.38} \mathrm{Pd}_{0.05} \mathrm{O}_{3}$ 의 페로브스카이트 산화물 을 자동차 배기가스 저감 장치에 들어가는 촉매로 사용 하였는데, 해당 산화물이 환원/산화 분위기에 따라 $\mathrm{Pd}$ 이 가역적으로 페로브스카이트 구조에서 빠져나와 금속 나노입자가 되었다가, 다시 산화분위기에서는 페로브스 카이트 구조에 녹아드는 현상을 발견하였는데, 이로 인 해 $\mathrm{Pd}$ 촉매의 수명이 굉장히 향상되었다는 사실을 보고 하였다. ${ }^{3)}$ 이는 현재 알려진 용출된 나노입자의 거동과 굉장히 비슷하다고 할 수 있다.

또한 2007년 S.A. Barnett 연구팀에서는 $\mathrm{La}_{0.8} \mathrm{Sr}_{0.2}$ $\mathrm{Cr}_{0.82} \mathrm{Ru}_{0.18} \mathrm{O}_{3}$ 페로브스카이스 산화물 연료극 기반 고체 산화물연료전지(solid oxide fuel cell, SOFC)를 구동하 던 중 전기화학적 성능이 초기성능에 2 배 가까이 증가하 는 사실을 발견하게 된다. 연구팀은 원인을 밝히기 위해 해당 페로브스카이트 산화물을 수소 분위기 (연료극 구 동조건)에서 열처리하였는데 표면에 $\mathrm{Ru}$ 나노입자들이 형성되어 있다는 사실을 발견하였다. ${ }^{4)}$

이후, 이러한 용출 현상은 앞서 소개한 Irvine 그룹에 의하여 재조명되었고, 이미 소개하였듯이 이 기법을 이 용해서 만들어낸 나노입자들을 활용한 다양한 연구들이 광범위하게 진행되었다. 특히 용출된 나노입자들은 전 기화학적 활용( $\mathrm{SOFC}$, 프로토닉 세라믹 연료전지, 알카
라인 수전해 등)을 필두로 하여, 화학촉매, 광촉매, 그리 고 산소전달체 등 폭넓게 활용되고 있다. 본고에서는 고 온 연료전지 전극촉매, 상온 물분해 전극촉매, 그리고 화학 촉매에 용출 현상이 활용된 사례들을 중점적으로 소개하겠다.

\section{2. 고체산화물 연료전지: 연료극}

고체산화물 연료전지의 연료극은 용출법이 가장 활발 하게 연구된 분야라고 할 수 있다. 고체산화물 연료전지 의 큰 장점 중 하나는 고온 작동(예 : $450{ }^{\circ} \mathrm{C} \sim 900{ }^{\circ} \mathrm{C}$ )을 이용한 내부 개질을 통해 수소 이외의 탄화수소를 연료로 쓸 수 있다는 것인데, Ni cermet을 중심으로 한 anode-supported cell들은 수소 연료를 기반으로 할 때 탁월한 성능을 보여주었지만, 탄화수소 연료를 기반 으로 할 때 $\mathrm{Ni}$ 에서 생기는 탄소 침적(carbon coking)으 로 인해서 내구성이 불안정하다는 문제가 있었다. 이에 따라서 ceramic을 기반으로 한 metal-free 세라믹 연 료극(예: $\mathrm{La}_{0.3} \mathrm{Sr}_{0.7} \mathrm{TiO}_{3-\delta}, \mathrm{Sr}_{2} \mathrm{Fe}_{1,5} \mathrm{Mo}_{0.5} \mathrm{O}_{5+\delta}$ 등) 소재들이 개발되고 있다. 하지만 이러한 연료극들은 carbon 침적 및 황 연료 불순물 등에 대한 저항성으로 뛰어난 가능성 을 보여준 것은 사실이었으나, electrolyte-supported cell 구조에서 오는 큰 Ohmic 저항과 metallic phase의 부재에서 오는 부족한 촉매 특성 및 전기 전도도의 이슈 가 있으며 결과적으로 그 성능이 기존 Ni-cermet을 뛰 


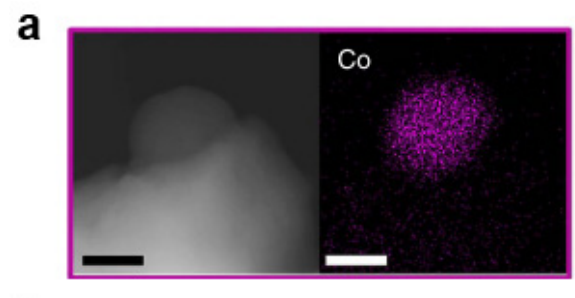

b
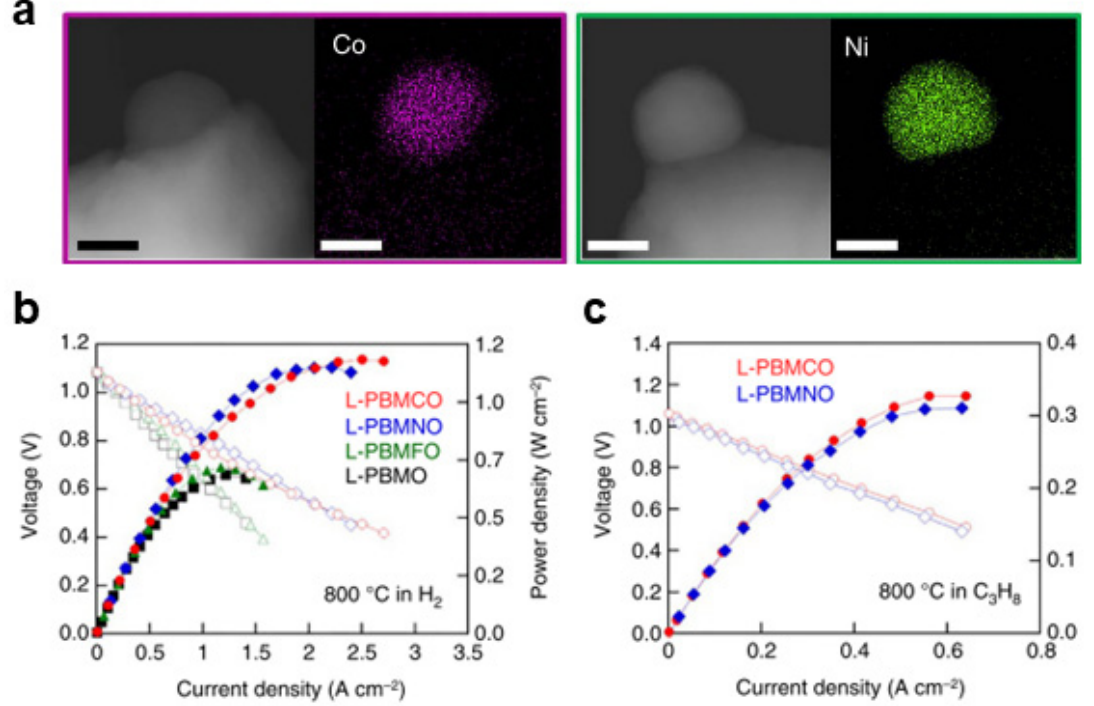

C

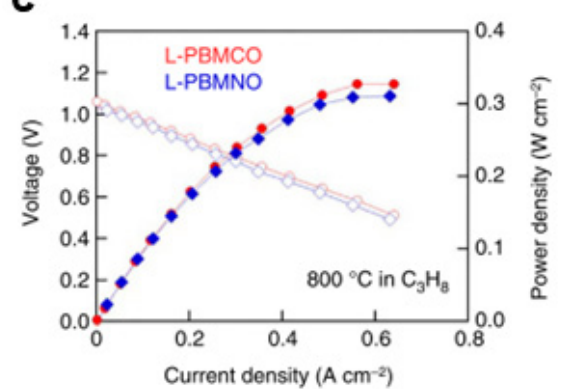

Fig. 5. (a) $\mathrm{Co}$ (왼쪽)와 Ni(오른쪽)의 용출을 보여주는 투과전자현미경사진과 원소성분분석 결과. $\mathrm{PrBaMn}_{2} \mathrm{O}_{5+\delta}$ 을 모상으로 하여 용출을 통해 만든 연료전지의 (b) 수소연료 기반 성능, (c) 프로판 연료 기반 성능'

어넘지 못하고 있다. 이러한 이슈를 해결하기 위해 최근 용출법에 의해 자발적으로 생성된 금속 나노 촉매를 활 용하여 부족한 촉매특성을 크게 보완한 ceramic 연료극 이 보고되고 있으며, 이들은 $\mathrm{Ni}$ cermet을 기반으로 하 는 전통적인 연료전지의 성능과 비슷하거나, 오히려 그 성능을 뛰어넘는 수준을 보여주어 경쟁력을 갖추기 시 작하였다.

김건태 교수와 한정우 교수 연구팀은 최근 더블 페로브 스카이트 산화물인 $\mathrm{PrBaMn}_{2} \mathrm{O}_{5+8}$ 에 $\mathrm{Co}, \mathrm{Ni}$ 을 도핑 한 후 용출법을 이용하여 금속 나노 촉매들을 얻어 내었고, 이 를 이용하여 연료전지를 구현하였다 (Fig. 5). ${ }^{5)}$ 그 결과 용출법을 적용하지 않은 연료전지에 대비하였을 때, 약 2 배 수준의 높은 성능을 보고하였다 (예: $\mathrm{L}-\mathrm{PBMCO}=$ $1.15 \mathrm{~W} \mathrm{~cm}^{-2} @ 800{ }^{\circ} \mathrm{C}$ 수소 연료 기준). 뿐만 아니라 이 렇게 용출 나노 촉매가 있는 연료극들은 탄화수소에 뛰어 난 저항성을 보여 프로판 $\left(\mathrm{C}_{3} \mathrm{H}_{8}\right)$ 에서도 높은 성능 $(0.331$ $\mathrm{W} \mathrm{cm}$ ) 과 200시간 동안 문제없이 작동함을 보고하였 다.

S.A. Barnett 연구팀은 $\mathrm{Fe}$ 과 $\mathrm{Ni}$ 의 합금(alloy) 인 $\mathrm{Fe}-\mathrm{Ni}$ 용출을 선보여 기존에 알려져 있었던 $\mathrm{SrTi}_{0.3} \mathrm{Fe}_{0.7} \mathrm{O}_{3-\delta}$ 연료극의 촉매 특성을 끌어 올렸다. 연
구팀은 합금 용출을 위해 소량의 $\mathrm{Fe}$ 를 $\mathrm{Ni}$ 로 치환하였 고, A-site deficiency를 주어 손쉬운 용출을 유도하였 다 $\left(\mathrm{Sr}_{0.95}\left(\mathrm{Ti}_{0.3} \mathrm{Fe}_{0.63} \mathrm{Ni}_{0.07}\right) \mathrm{O}_{3-\delta}\right)$. ${ }^{6}$ 그 결과 $\mathrm{Fe}-\mathrm{Ni}$ 합금이 용출된 연료전지는 $\mathrm{H}_{2}$ 산화에 더 뛰어난 촉매 특성을 보 여주었고 $850{ }^{\circ} \mathrm{C}$ 에서 $1.3 \mathrm{~W} \mathrm{~cm}^{-2}$ 의 최대전력출력밀도 를 보고하였다. 합금 촉매의 장점은 낮은 수소 분압에 서 더 두드러지게 나타났는데, $750{ }^{\circ} \mathrm{C}$ 를 기준으로 $30 \%$ wet $\mathrm{H}_{2}$ 연료를 사용하였을 때 최대전력출력밀도는 용출 을 하지 않은 연료전지와 비교하였을 때 대략 3 배 가까 운 차이를 보여주었다. 연구팀은 이를 $\mathrm{Fe}-\mathrm{Ni}$ 합금 촉매 가 $\mathrm{H}_{2}$ adsorption에 크게 기여하기 때문이라고 해석하 였고, 이 연료전지는 syngas $\left(50 \% \mathrm{H}_{2} / 50 \% \mathrm{CO}\right)$ 연료에 서도 200 시간 동안 문제없이 작동하여 $\mathrm{CO}$ 피독에도 문 제가 없음을 시사하였다.

이 외에도 다양한 모상 (예: $\mathrm{La}_{0.75} \mathrm{Sr}_{0.25} \mathrm{Cr}_{0.5} \mathrm{Mn}_{0.5} \mathrm{O}_{3-\delta}$, $\mathrm{Sr}_{2} \mathrm{Fe}_{1,5} \mathrm{Mo}_{0,5} \mathrm{O}_{5+\delta}$ 등)에 대해서 다양한 종류의 전이금속 (예: $\mathrm{Fe}, \mathrm{Cu}, \mathrm{Ni}, \mathrm{Co}$ 등)의 용출이 활발히 연구되고 있 으며, 합금 용출이 가지는 진보된 촉매 특성에 대해서도 학계의 관심이 쏠리고 있다. ${ }^{7,8)}$

\section{3. 고체산화물 연료전지: 공기극}




\section{특 집}
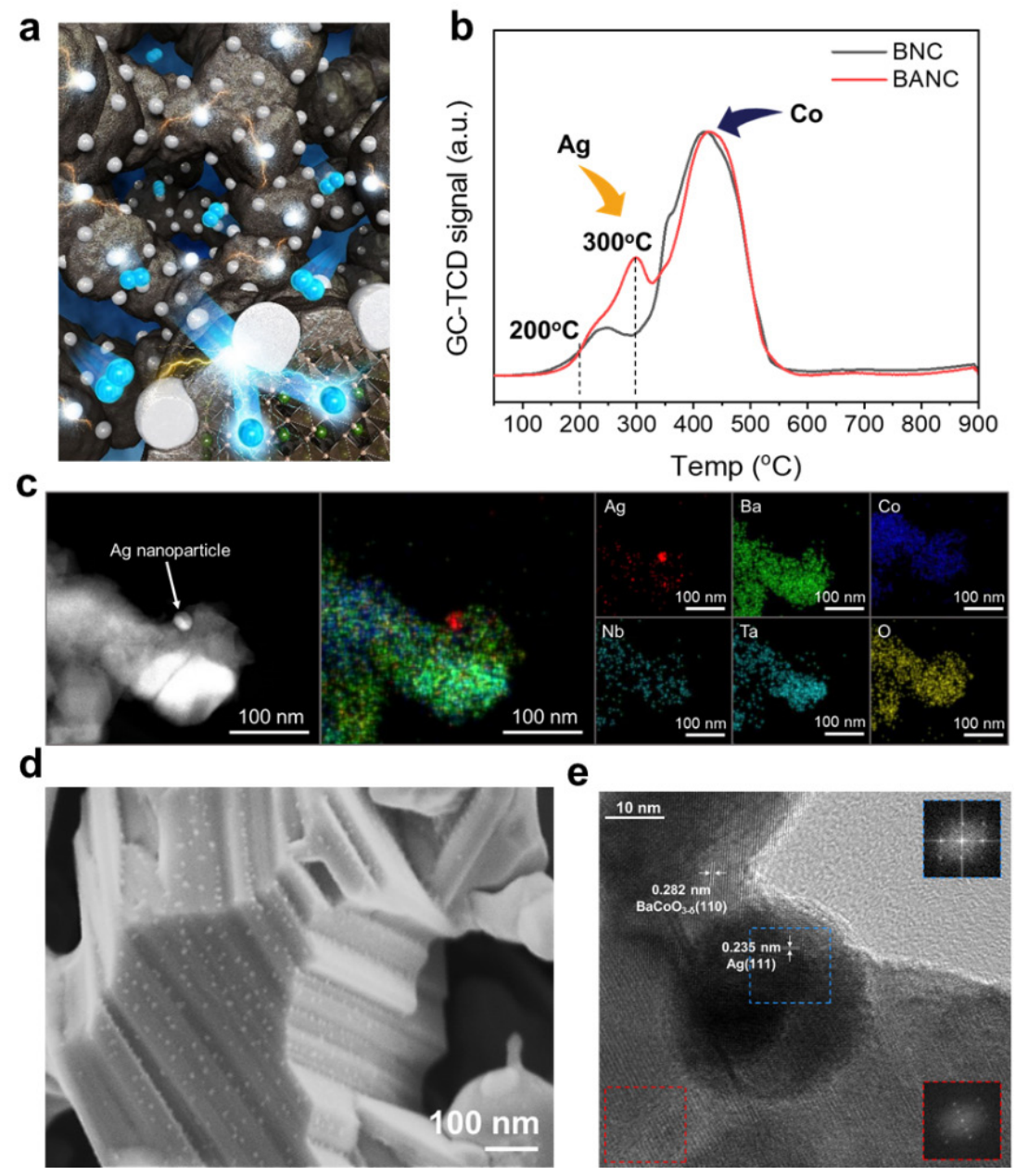

e

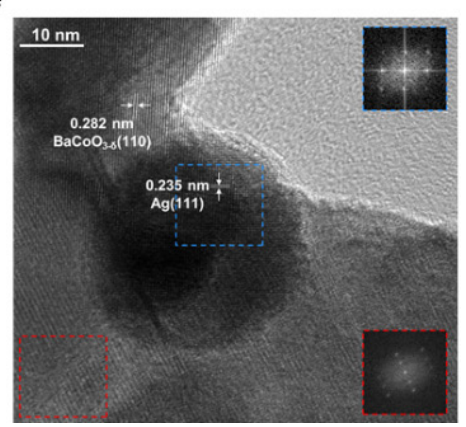

Fig. 6. (a) 페로브스카이트 산화물 위에서 Ag가 산소 환원 반응을 촉진하는 것을 나타낸 Fig.. (b) $\mathrm{H}_{2}-\mathrm{TPR}$ 을 통한 $\mathrm{Ag}$ 를 도핑한 샘플과 도 핑하지 않은 샘플의 비교 예시, (c) $\mathrm{EDX}$ 원소 분석을 통한 $\mathrm{Ag}$ 나노입자의 확인. (d) $\mathrm{Ag}$ 나노입자의 용출을 나타낸 주사전자현미경 사진, (e) 부분적으로 박혀있어 열적 안정성을 확보한 $\mathrm{Ag}$ 를 나타낸 투과전자현미경 사진. ${ }^{10)}$ Advanced Functional Materials의 게재 허가를 받음.

연료전지의 연료극(Anode) 같은 경우는 환원 분위기 이므로, 용출법을 사용하여 나노입자를 얻기 가장 이상 적인 환경이라고 할 수 있다. 하지만 연료전지의 공기극 (Cathode)는 산소가 존재하는 산화 분위기이므로 용출 법을 사용하기 상대적으로 까다롭다. 하지만 용출된 나 노 입자의 뛰어난 촉매 특성을 활용하기 위한 일환으로 최근에는 $\mathrm{SOFC}$ 공기극에서도 이 현상을 활용한 사례들 이 보고되고 있다. Meilin Liu와 Zongping Shao 연구 진은 $\mathrm{Sr}_{0.95} \mathrm{Nb}_{0.1} \mathrm{Co}_{0.9} \mathrm{O}_{3}$ 의 페로브스카이트 산화물에 $\mathrm{Ag}$ 를 도핑하여 용출법을 활용하였는데, 이는 $\mathrm{Ag}$ 가 가지
는 뛰어난 산소 환원 촉매 특성을 활용하기 위함이다. ${ }^{9}$ 연구팀은 환원 분위기에서 불안정한 cobalt-based 산 화물을 보호하고 선택적으로 $\mathrm{Ag}$ 만 용출해내기 위해서 $\mathrm{H}_{2}$ - temperature programmed reduction $\left(\mathrm{H}_{2}-\mathrm{TPR}\right)$ 기법을 활용하였다. 이 방법을 통해서 $\mathrm{Ag}$ 를 도핑한 샘 플과 도핑하지 않은 샘플을 비교한 결과 $\mathrm{Ag}$ 가 도핑된 샘플만이 $\mathrm{Co}$ 가 환원되기전 $\mathrm{Ag}$ 만이 용출되는 선택적 온 도구간이 있다는 것을 확인하고, 이 온도 범위에서 제 한된 환원 열처리를 진행하여, 모상의 구조를 지키면서 $\mathrm{Ag}$ 나노 입자만을 표면에 얻어내는데 성공하였다. 
비슷한 방식으로 본 연구팀은 $\mathrm{BaCoO}_{3}$ 를 기반으로 한 페로브스카이트 산화물에 $\mathrm{Ag}$ 용출을 이용하여 뛰어 난 성능의 SOFC 셀을 구현한 바 있다 (Fig. 6). ${ }^{10)}$ 따라 서 $\mathrm{H}_{2}-\mathrm{TPR}$ 을 이용하여 용출될 원소와 모상의 환원 경 향성을 얻어내고, 이를 통해서 모상의 파괴없이 금속 나 노 촉매를 얻어내는 것은 용출법을 연료전지 공기극에 활용하기 위한 가장 핵심적인 전략이라고 할 수 있겠다. $\mathrm{Ag}$ 이외에도 상대적으로 환원이 쉬운 $\mathrm{Ni}, \mathrm{Pd}, \mathrm{Pt}$ 등이 연료전지 공기극에서 용출법을 이용해 공기극 촉매로서 활용될 여지가 있을 것으로 전망된다.

\section{4. 물분해 전극촉매}

현재까지, 용출법을 이용한 대다수의 연구가 고온 기 반의 응용분야에서 주로 사용되었지만, 최근에는 저온 전기화학 촉매 분야에서도 활용되며 우수한 활성도와 내구성을 보여주고 있다. 특히, 염기성 수용액 기반에서 의 수전해 반응에 효과적으로 사용되고 있다. 수전해 반 응은 크게 수소생성반응 (HER) 과 산소생성반응 (OER) 으로 나눌 수 있다. 수전해 반응에서는 일반적으로, 산 소생성반응이 반응속도결정단계라고 알려져 있기 때문 에, 전체 수전해 반응을 증진시키기 위해서는 산소생성 반응성을 증진시켜야 한다. 따라서, 이러한 저온 기반 전기화학 촉매 분야에서는 촉매들의 산소생성반응의 반 응성에 관한 연구들이 활발히 진행되고 있다.

$\mathrm{S}$. Song과 공동 연구자들은 $\mathrm{LaCo}_{0.8} \mathrm{Fe}_{0.2} \mathrm{O}_{3}$ 페로브스 카이트계 촉매에서 환원열처리 전/후에 따른 산소생성 반응 특성 평가를 진행하였다. ${ }^{11)}$ 그 결과, 환원 열처리 이후, $\mathrm{La}_{2} \mathrm{O}_{3}$ 지지체 위에 $\mathrm{CoFe}$ 금속 나노촉매를 용출 되는 것을 확인하였고, $0.1 \mathrm{M} \mathrm{KOH}$ 수용액에서 매우 높 은 수준의 질량당 활성도 $(40.8 \mathrm{~A} / \mathrm{g})$ 와 과전압 값 $(293$ $\mathrm{mV}$ )을 보고하였다. 이는 환원열처리 전의 촉매의 질량 당 활성도의 40 배에 해당하는 값으로, 용출법 적용 이후 엄청난 성능 증진을 나타냈다. 뿐만 아니라, 해당 연구 자들은 100 시간 동안의 구동을 성공하여 높은 안정성 역시 보고하였다.

추가적으로, 이러한 수용액 기반의 전기화학 분야 에서는 용출법으로 합성 및 분산된 금속 나노촉매의
기능화를 이용하는 것이 새로운 기법으로써 이용되 기 시작하는 단계이다. 그 예로, 나노촉매의 인처리 (phosphatization)이 이용되고 있다. Y. Wang과 공동 연구자들은 $\mathrm{La}_{0.8} \mathrm{Sr}_{0.2} \mathrm{Cr}_{0.69} \mathrm{Ni}_{0.31} \mathrm{O}_{3}$ (LSCN) 페로브스카 이트계 촉매 용출기법과 인처리 기법을 사용하여 산소 생성반응 특성 평가를 진행하였다. ${ }^{22}$ 그 결과, $\mathrm{LSCN}$ 지 지체 위에 $\mathrm{Ni}_{2} \mathrm{P}$ 나노입자가 형성된 것을 XPS, $\mathrm{SEM}$ 그 리고 TEM 분석을 통해 확인하였고, $0.1 \mathrm{M} \mathrm{KOH}$ 수용 액에서 약 $410 \mathrm{mV}$ 라는 과전압 값을 보고하였다. 추가 적으로, $470 \mathrm{mV}$ 과전압에서 질량당 활성도를 비교하였 고, 인처리를 한 이후, 약 10 배 성능을 개선하였다.

\section{5. 화학반응 촉매}

용출법이 적용되었다고 앞서 언급된 다양한 응용분야 는 크게 전기화학 촉매로 분류할 수 있다. 그러나 용출 법은 화학 촉매 분야에서도 핵심기술로서 최근 많이 사 용되고 있다. 특히, 해당 분야에서는 용출법과 동일한 현상이지만, 다른 용어로 불리기도 하였는데, 본 논문에 서는 이들을 모두 용출법으로 통일하여 적용된 사례를 정리한다.

이러한 화학 촉매 분야에서, 용출법이 가장 많이 사용 된 곳은 엔진에서 배출되는 배기가스 내의 유해물질을 줄이기 위한 삼원촉매 (Three-way catalysts) 분야라 할 수 있다. 이 촉매는 탄화수소계 물질이나 일산화탄소 를 산화시키고, 질소 산화물 $\left(\mathrm{NO}_{\mathrm{x}}\right)$ 를 줄이는 반응의 핵 심기술이라 할 수 있다. 앞서 Intelligent catalyst라는 용어를 사용한 Y. Nishihata를 포함한 공동연구자들은, $\mathrm{LaFe}_{0.57} \mathrm{Co}_{0.38} \mathrm{Pd}_{0.05} \mathrm{O}_{3}$ 물질에서 산화/환원 분위기에 따 라 $\mathrm{Pd}$ 나노입자의 용출과 용해를 성공적으로 관찰하고, 우수한 성능을 구현함과 동시에 일반적인 담지 촉매보 다 월등한 안정성을 보고한 바 있다. ${ }^{3)}$

일반적으로 담지 촉매가 동일한 양의 활성 금속양을 가지는 조건에서 높은 반응성을 가지기 위해서는, (1) 더 넓은 비표면적을 가지는 지지체 산화물 위에, (2) 더 작 고 많은 수의 금속 나노촉매가 도포되어야 한다. 그러 나 최근, 용출법으로 만들어진 담지 촉매가 이러한 일반 적인 요구조건에도 불구하고 특히 높은 반응성을 지니 


\section{특 집 ㅁㅃ 김준혁1, 김준규1, 정우철 ${ }^{\dagger}$}
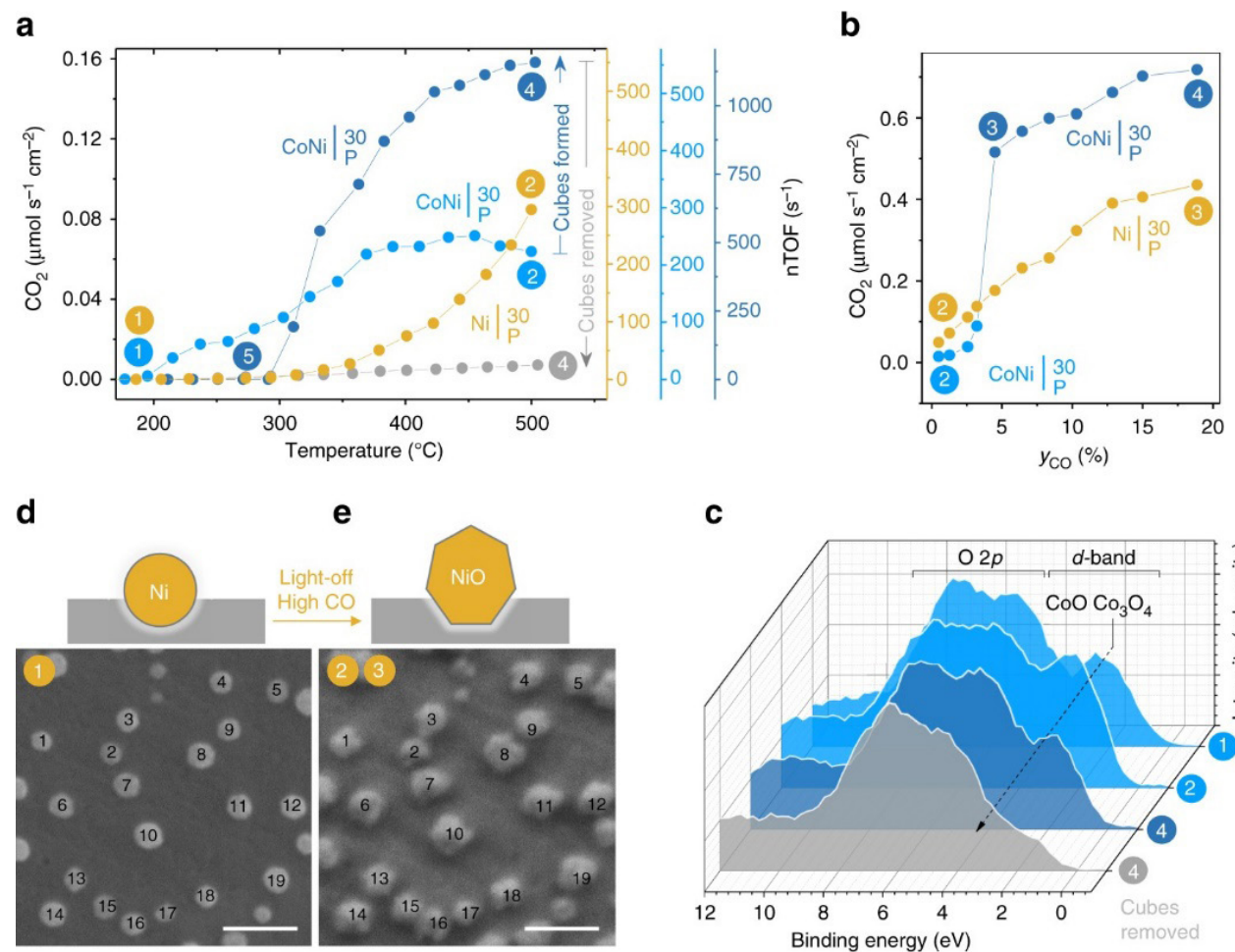

e

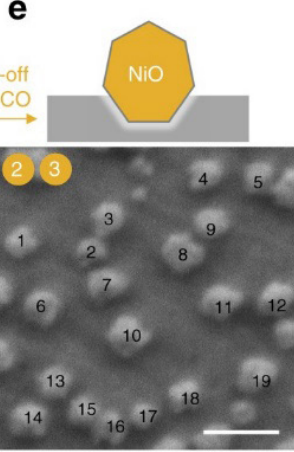

C

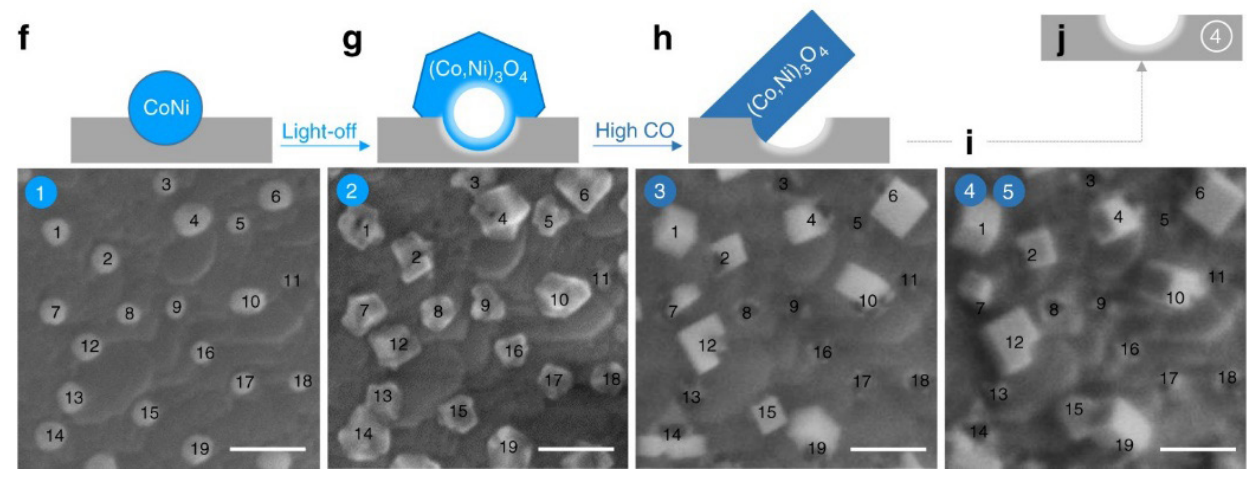

Fig. 7. 용출된 나노입자의 재구성 및 해당하는 촉매 특성 변화. (a) CO 산화반응 (b) CO 농도에 따른 촉매 반응성 (c) Co 촉매의 화학상태

(d-j) 반응 조건에 따른 주사전자현미경 이미지 ${ }^{2}$.

는 연구가 보고되었다. C. Tang과 그 공동 연구자들은, $\mathrm{La}_{0,43} \mathrm{Ca}_{0,37} \mathrm{Ti}_{0,99} \mathrm{Rh}_{0,01} \mathrm{O}_{3}$ 물질에서 용출법으로 만들어진 담지 촉매와, 같은 $\mathrm{Rh}$ 양을 $\mathrm{Al}_{2} \mathrm{O}_{3}$ 지지체 위에 함침하여 만든 담지 촉매의 반응성을 $\mathrm{CO}$ 산화 반응으로 비교하였 다. ${ }^{13)}$ 그 결과, 용출법으로 합성된 담지 촉매의 비표면 적이 함침법으로 만든 촉매보다 횔씬 작았고, 그리고 금 속 나노촉매의 크기가 훨씬 크고 개수가 적었음에도 불

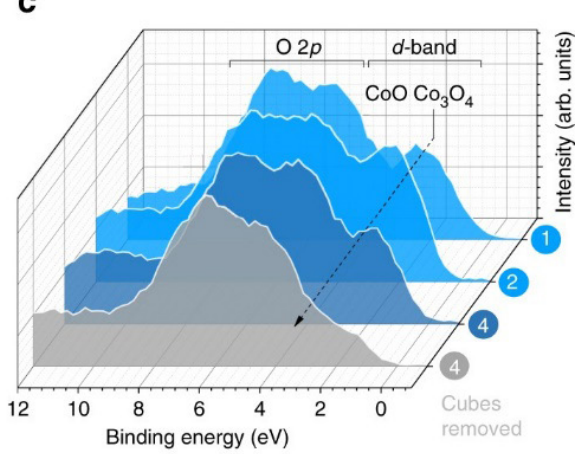

구하고 일반 함침법으로 만든 담지 촉매와 거의 유사한 $\mathrm{CO}$ 변환 성능을 보고하였다. 하지만 그 이유에 대해서 는 여전히 밝혀지지 않았으며, 용출법으로 합성된 금속 나노촉매의 비이상적으로 우수한 특성에 대해서는 추후 많은 연구들이 수반될 필요가 있다.

이외에도, 용출법으로 합성 및 분산된 금속나노입 자의 특이한 촉매적 활성도를 보여주는 연구사례가 최 
근 일부 보고된 바 있다. D. Neagu와 공동연구자들은, $\mathrm{La}_{0.8} \mathrm{Ce}_{0.1} \mathrm{Ni}_{0.4} \mathrm{Ti}_{0.6} \mathrm{O}_{3}$ 와 $\mathrm{La}_{0.7} \mathrm{Ce}_{0.1} \mathrm{Co}_{0.3} \mathrm{Ni}_{0.1} \mathrm{Ti}_{0.6} \mathrm{O}_{3}$ 물질 을 사용하여 각각 $\mathrm{Ni}$ 나노입자와 $\mathrm{CoNi}$ 합금 나노입자 를 용출시켜 $\mathrm{CO}$ 산화반응 활성도를 측정하였고, 동시에 반응 도중의 나노입자의 모양과 분포변화를 분석하였다 (Fig. 7). ${ }^{14)}$ 이를 바탕으로, $\mathrm{CO}$ 산화 반응 중의 조건에 따라, 그리고 나노입자의 조성에 따라 나노입자의 형태 가 달라지는 것을 밝혀내었고, 특히 높은 $\mathrm{CO}$ 농도에서 의 $\mathrm{CO}$ 산화반응에서, 용출된 $\mathrm{CoNi}$ 합금 나노입자의 매 우 높은 활성도가 나타난다는 것을 보고하였다.

\section{4. 맺음말}

본 논문에서는 차세대 지지 촉매 개발 기술인 용출법 에 대한 배경지식과 더불어 사용되는 응용분야에 대해 체계적으로 정리하였다. 용출법은 현재 불균일계 촉매 분야에서 최근 크게 주목받고 있는 원천 소재기술이며, 세라믹 산화물 표면에 금속/세라믹 계면을 자발적으로 만들어 내는 기능성 계면 제어 기술이다. 관련하여, 많 은 기초 및 응용 연구들이 이루어지고 있지만, 범용적인 촉매 선택 혹은 디자인에 대한 기술은 여전히 부족한 실 정이며, 일부 보고되는 특별한 여러 특성들 (높은 황피 독 저항성, 특이하게 우수한 성능)에 대한 이유 역시 명 확하게 밝혀진 바가 없다. 이에 따라, 추후에는 이러한 기술개발에 관한 심층적인 기초 연구가 더욱 절실히 필 요하다.

\section{REFERENCES}

1. Neagu, D., Tsekouras, G., Miller, D. N., Menard, H. \& Irvine, J. T. In situ growth of nanoparticles through control of nonstoichiometry. Nat. Chem., 5, 916-923, doi:10.1038/nchem.1773 (2013).

2. Neagu, D. et al. Nano-socketed nickel particles with enhanced coking resistance grown in situ by redox exsolution. Nat. Commun., 6, 8120, doi:10.1038/ncomms9120 (2015).

3. Nishihata, Y. et al. Self-regeneration of a Pd-perovskite catalyst for automotive emissions control. Nature, 418, 164-167 (2002).

4. Madsen, B. D., Kobsiriphat, W., Wang, Y., Marks, L. D. \& Barnett, S. A. Nucleation of nanometer-scale electrocatalyst particles in solid oxide fuel cell anodes.

J. Power Sources, 166, 64-67, doi:10.1016/ j.jpowsour. 2006.12.080 (2007).

5. Kwon, O. et al. Exsolution trends and co-segregation aspects of self-grown catalyst nanoparticles in perovskites. Nat. Commun., 8, 15967, doi:10.1038/ncomms15967 (2017).

6. Zhu, T., Troiani, H. E., Mogni, L. V., Han, M. \& Barnett, S. A. Ni-Substituted $\mathrm{Sr}(\mathrm{Ti}, \mathrm{Fe})$ O3 SOFC Anodes: Achieving High Performance via Metal Alloy Nanoparticle Exsolution. Joule, 2, 478-496, doi:10.1016/j.joule.2018.02.006 (2018).

7. Du, Z. et al. High-Performance Anode Material Sr2FeMo0.65Ni0.35O6-delta with In Situ Exsolved Nanoparticle Catalyst. ACS Nano, 10, 8660-8669, doi:10.1021/acsnano.6b03979 (2016).

8. Lu, J. et al. Highly efficient electrochemical reforming of $\mathrm{CH} 4 / \mathrm{CO} 2$ in a solid oxide electrolyser. Sci. Adv., 4, eaar5100 (2018).

9. Zhu, Y. et al. Promotion of Oxygen Reduction by Exsolved Silver Nanoparticles on a Perovskite Scaffold for Low-Temperature Solid Oxide Fuel Cells. Nano Lett., 16, 512-518, doi:10.1021/acs.nanolett.5b04160 (2016).

10. Kim, J. H. et al. Ex-Solved Ag Nanocatalysts on a Sr-Free Parent Scaffold Authorize a Highly Efficient Route of Oxygen Reduction. Adv. Funct. Mater., n/a, 2001326 , doi:10.1002/adfm. 202001326.

11. Song, S. et al. Operando X-ray spectroscopic tracking of self-reconstruction for anchored nanoparticles as high-performance electrocatalysts towards oxygen evolution. Energy Environ. Sci., 11, 2945-2953, doi:10.1039/c8ee00773j (2018).

12. Wang, Y. et al. Enhanced overall water electrolysis on a bifunctional perovskite oxide through interfacial engineering. 


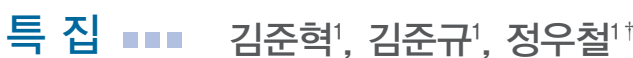

Electrochim. Acta, 318, 120-129, doi:10.1016/ j.electacta.2019.06.073 (2019).

13. Tang, C. et al. Towards efficient use of noble metals via exsolution exemplified for CO oxidation. Nanoscale, 11, 16935-16944, doi:10.1039/c9nr05617c (2019).

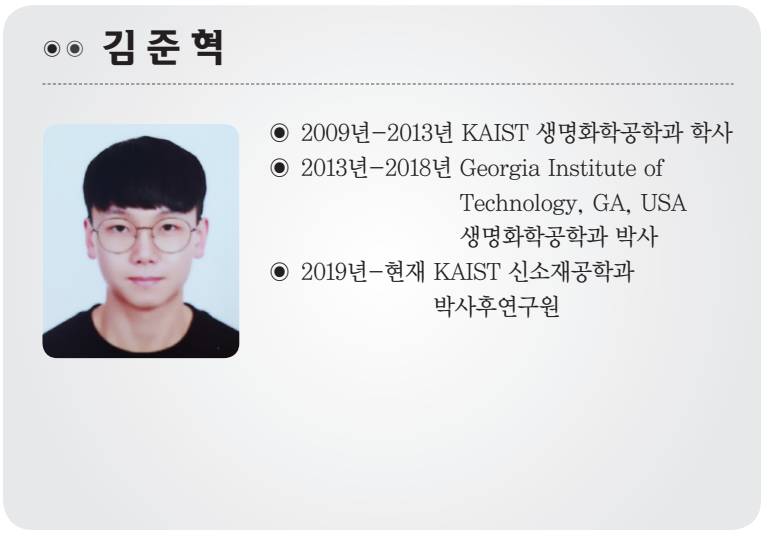

\section{정 우 철}

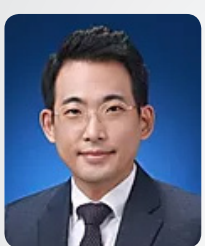

( 2004년 서울대학교 재료공학부 학사

- 2010년 MIT, MA, USA 신소재공학과 박사

○ 2010년-2013년 Caltech, CA, USA 신소재공학과 박사후연구원

- 2013년-2018년 KAIST 신소재공학과 조교수

( 2) 2018년-현재 KAIST 신소재공학과 부교수
14. Neagu, D. et al. Demonstration of chemistry at a point through restructuring and catalytic activation at anchored nanoparticles. Nat. Commun., 8, 1855, doi:10.1038/s41467-01701880-y (2017).

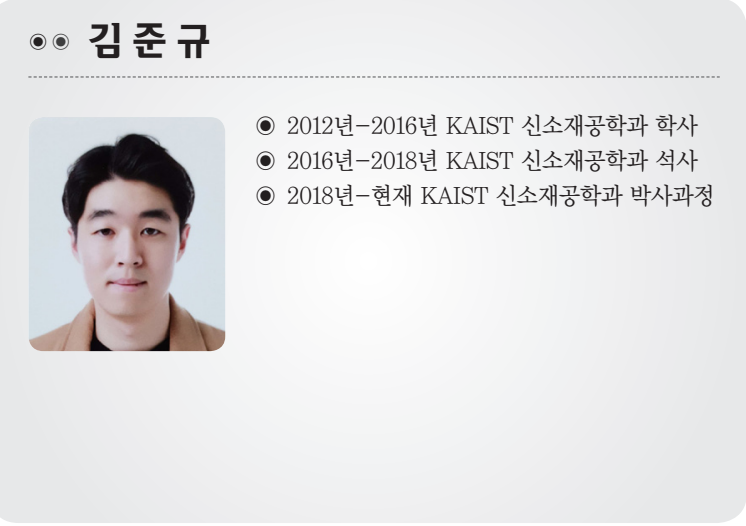

